\title{
Research on Chinese Culture Infiltration in College English Translation
}

\author{
Liu Xiaoyi \\ Foreign Language Department \\ Jilin Business and Technology College \\ Changchun, China \\ 182076127@qq.com
}

\begin{abstract}
In non-English major college English teaching in China, cultural introduction is attached much importance to but cultural output is greatly ignored, so cultural aphasia phenomenon is serious, affecting the effects of spreading Chinese culture to the world. Based on the question types reform of CET 4 and CET 6 in college English translation and some problems existing in current teaching, this paper aims to explore the significance of Chinese traditional culture in college English translation teaching and points out that college English teaching on the basis of cultivating the five English application abilities, translation, listening, speaking, reading and writing, must expand the target of English teaching to improve students' cultural communication. Through cleverly integrating Chinese culture in English teaching content, it not only enhances the teaching level of college English translation, but also improves students' English and translation ability, which will be of great help for cultivating students' intercultural communicative competence.
\end{abstract}

Keywords-College English; Translation teaching; Chinese culture

With the reform and opening and globalization, English as a second language has long been highly valued in China, but in the process of Chinese culture being developed on the international stage, English has not given its full play to the due effect. Cultural introduction is attached much importance to but cultural output is greatly ignored, so Chinese culture aphasia phenomenon is serious. The strategy of "Chinese culture stepping out into the world" puts forward new requirements and huge challenges for college English teaching. In recent years, the question types of translation in CET 4 and CET 6 have been greatly changed from the single sentence translation in the past to paragraph translation from Chinese into English, which causes many students to lose points in the exam and also reflects some of the problems existing in the current English teaching. We should seriously analyze the existing problems in order to timely adjust in the college English translation teaching and improve the effect of college English translation teaching.

\section{The Plight of College English Translation TEACHING-CHINESE CULTURE APHASIA}

The plight of traditional college English teaching is grammar, vocabulary and rhetoric features as the main line throughout the whole teaching process, ignoring the most important function of language, namely, ideological and cultural exchanges. In recent years, despite the increase of culture teaching, but in the aspect of culture communication ability, college English teaching is not very desirable in that it ignores the localization trend of the English language and culture teaching in the process of the globalization development, leading to serious phenomenon of "Chinese culture aphasia”. As a consequence, the high-quality talents cultivated commonly lack the ability to use English to spread Chinese culture. The author, through participating in the reform and marking work of CET 4 and CET 6 and front line teaching experience, sums up the reasons why college students lose points in the translation of CET 4 and CET 6, mainly including the following two aspects:

First, college students lack of a great amount of English vocabulary. New version of the translation subject involves China's history, culture, economy, science and technology, social development and many other areas, which has higher requirements to the vocabulary and phrasing ability of students. In December 2013, for example, the question in CET 4 required students to translate “瑰宝”, however, a considerable number of students failed to translate it into "treasure". Second, students' understanding of Chinese is not accurate enough sometimes. In the limited test time, students need experience a rapid transformation between two languages in their minds. Without essential comprehension and application of Chinese language, it is easy for them to misunderstand and mistranslate. In addition, the lack of consciousness of the related language and culture causes students to adopt inflexible translation method and handing questions improperly. Even though before test they have accepted specialized training in translation method and strategy, many students still cannot adapt themselves to the changing circumstance when facing specific problems and work out an accurately and fluently expressed target translation. For another example, in December 2013, there appeared the word “辟 邪” in the translation of CET 4, it seems hard to translate, but according to its cultural connotation, the word can be liberally translated into "sweep away ill fortune" through flexible processing[1]. 


\section{The CURRENT PROBlems OF COLLEGE ENGLISH TRANSLATION TEACHING}

From the above mentioned problems in CET translation, CET 4 and CET 6 have set a higher standard for students' competence in vocabulary, translation method and cultural literacy. At the same time, it also forms a great challenge to college English translation teaching and causes our reflection on the problems existing in the current college English translation teaching.

First, the vocabulary teaching is limited in the textbook glossary and college English texts are all selected from the original articles in English countries, through the learning in the classroom, students are accessible to contacting with foreign culture, education, science and technology, therefore, the related words in the translation of Chinese native culture are very few. This to a large extent affects the C-E translation, making them have nothing more to say in the translation of relevant articles to traditional culture, handing the translation problems with high proficiency and getting trapped in the dilemma when encountering related translation work in the future work.

Secondly, the current teaching method of translation is too mechanical, putting too much emphasis on training students' language level, however, cultural translation method as a special difficulty in teaching has not been highlighted. Students, through accepting translation training in sentence translation, can easily deal with simple sentence translation. However, in face of the translation articles with profound cultural features, especially when translating idioms, allusions or other cultural expressions, they can hardly cope with the translation problems with ordinary translation method. American translation theorist Eugene Nida pointed out: "translation is the communication between two cultures. To a real successful translator, it is more important to have an intimate knowledge of two cultures than to have a grasp of two languages.” Because words only make sense in the cultural background where they act, the translation process will be restricted by the source language culture and target language culture[2]. Therefore, cross-cultural knowledge culture should become the focus of the student to study translation, especially in college English translation classroom in China, Chinese traditional culture should be infiltrated into translation teaching and teachers should realize the importance of strengthening cultural translation as a principal role in college English teaching.

\section{SignificANCE OF ChINESE TRADITIONAL CULTURE IN COLLEGE ENGLISH TEACHING}

In recent years, the requirement of college English education in our country is increasingly higher, for the purpose of cultivating students' comprehensive ability to apply English so as to make them communicate effectively in English in the future study, work and social activities. This is a new requirement put forward in China for the cultivation of the intercultural communicative competence of the high-quality talents in college English teaching. The world economic integration makes the demand for English increasingly wide, and college English teaching has to reposition its function and target in order to establish the cross-cultural position of college
English teaching. To successfully achieve intercultural communication, a certain understanding of the native culture and the target culture is a must. However, English teaching in China, because of its too much emphasis on British and American culture for many years, lacks of Chinese culture in college English teaching, which leads to the "Chinese cultural aphasia" as a common phenomenon among English learners in China. As a matter of course, students in our country feel it difficult to express native culture in English in cross-cultural communication, causing foreigners' misunderstanding of Chinese culture because of unclear expression. There also appears "culture shock" phenomenon due to lack of language ability. From the perspective of English teaching, culture teaching is an inevitable trend in translation teaching. Today's language research has shifted from a study of text into the study of culture. English translation teaching should also reflect this change can apply the latest research achievements of language in classroom teaching, making students realize that language translation is a cultural activity, the essence of translation is a cross-cultural communication, the understanding of the different languages cannot be separated from regional culture and era background. In view of the fact that current college English translation teaching cannot satisfy the students' high demand, which should be adjusted according to the status quo of the teaching, making college English translation course after the reform can better adapt itself to the level of CET 4 and CET 6 and the high requirements of the college students' English ability in today's society. Increase or addition of the English translation vocabulary of Chinese traditional culture can effectively improve students' translation level and speed and solve the widespread problem of "Chinese cultural aphasia" in the current college English teaching[3]. Additionally, the expression ability and skill of idioms, allusions or other Chinese traditional culture should be trained to help students improve their level and quality of translation. In addition, through the inclusion of Chinese traditional culture in the English translation teaching, it also can strengthen student's quality education and improve cross-cultural communication competence. Through the study of rich and colorful culture, it can stimulate students' interest in learning English, promote the construction of vibrant college English classroom, help students set up the correct cultural consciousness and carry forward the excellent cultural tradition of the Chinese nation. It is also beneficial to improving teachers and students' cultural attainment, improve the lack of Chinese culture in college English teaching, help to explore the necessity and feasibility of the traditional culture contents in college English teaching and provide reference for the followup construction of college English course system[4].

\section{Fusing Traditional Chinese Culture in College ENGLISH TRANSLATION}

Fusing Chinese traditional culture in college English translation can effectively improve students' English and translation ability. In classroom teaching practice, teachers also need to pay attention to some methods in order to better enhance the level of college English translation teaching.

First of all, teachers should guide students to extend the useful vocabulary of Chinese traditional culture in English 
translation. Some words lacking in college English teaching text can be added by means of example sentence explanation, classroom practice or after-class exercise. For example, “秀 才” can be translated as “scholar” because the word “秀 才” generally refers to the ancient scholars or intellectuals at that time. Although students know the meaning of "scholar" , without teachers' inspiration, it is difficult for them to quickly work out a simple and suitable translation of the English vocabulary. In addition, some students easily translate “天下 事” into "things under the sky" or "what's going on in the world”, which will cause misinterpretation for target readers. Under the guidance of the teacher, students can properly translate it into "the wide world's affairs". So, students can learn many words relevant to Chinese traditional culture in the examples of English and us them in different contexts in translation[5].

Second, teachers can help students accumulate some idioms and proverbs containing Chinese traditional culture. Idiom translation is the special difficulty in translation teaching from Chinese into English, because it is a fixed expression being used by ordinary people for a long time with a strong national colors and distinctive cultural connotation, which is the accumulation of national culture and requires students find out the deep meaning of idioms when stay on the surface of the text to break communication and cultural differences of two languages. Therefore, teachers, when translating idioms, are supposed to help students correctly understand deep culture, especially some rarely used ancient language in modern society. For example, in A Dream of Red Mansions, Wang Xifeng said with smile “你倒会拉长线儿.......” , in which “拉长线” is another way of expressing “放长线钓大鱼” and can be translated as "look ahead" using metaphor images with similar synonymous English idioms. This translation cannot vividly reflect the artistic quality of the original text, but it has reflected the meaning of "throw a long line to catch a big fish" properly. In this process, students have a deeper understanding of Chinese cultural knowledge and stimulate their learning interest in translation[6].

At last, translation teaching should also focus on "teach him to fish, rather than giving him fish", so teachers should teach students useful translation strategies. Some Chinese idioms are popular and easy to understand, whose meanings can be directly expressed with literal interpretation, so literal translation method can be used. For example, “纸老虎” can be directly translated into " paper tiger" with literal translation, showing the incisive and vivid Chinese cultural connotations for the foreign readers. Some Chinese proverbs are with the similar intercultural meaning to English proverbs, although there are differences in language habits and cultural background, borrowing strategy can be adopted. For example, “物以类聚,人以群分” can be translated as “birds of a feather flock together” and “船到桥头自然直” can be translated into "you will cross the bridge when you come to it." There are also liberal translation, namely, during the translation of idioms and proverbs, giving up the original image and only translating its metaphorical meaning. For example, “拔苗助长” is translated into "spoil things by excessive enthusiasm."[7]

In addition, students can choose another kind of translation method, such as adding the background and history as annotation according to the specific context. Here is an example. In many regions of China, the translation of regional culture is relatively difficult, so, students' can work out a most proper and accurate translation according to their understanding of regional culture. Table 1 is a translation example of Shan Xi culture in college English translation class.

TABLE I. A COMPARISON OF TRANSLATION FROM ST TO TT1 AND TT2

\begin{tabular}{|c|c|c|}
\hline ST & TT1 & TT2 \\
\hline $\begin{array}{l}\text { 房子半边盖 } \\
\text { 帕帕头上戴 } \\
\text { 姑娘不对外 } \\
\text { 面条像腰带 } \\
\text { 锅盔像锅盖 } \\
\text { 辣子是道菜 } \\
\text { 唱戏吼起来 }\end{array}$ & $\begin{array}{l}\text { The Eight Fantasticalities in Shaanxi area-- } \\
\text { People prefer squatting on the ground over sitting on a bench } \\
\text { The roof of a house has only one sloping plane } \\
\text { People enjoy wearing a handkerchief on the head } \\
\text { Girls never go and marry out of their local districts } \\
\text { The noodle is in the shape of a waist-belt } \\
\text { The pancake is in the shape of a Chinese pan cover } \\
\text { Chilli itself can be a dish } \\
\text { The local opera is performed by shouting vigorously instead of singing }\end{array}$ & $\begin{array}{l}\text { The eight oddities in Shaanxi area-- } \\
\text { Wooden stool is used to squat on } \\
\text { The house is built only half rooftop } \\
\text { Women wear handkerchief to cover their hair and never marry the } \\
\text { foreigner } \\
\text { Noodle is in the shape of a waist-belt } \\
\text { Baked cake looks like the lid of a stewpot } \\
\text { Hot pepper is a delicacy } \\
\text { The local opera Qin Qiang is howled out }\end{array}$ \\
\hline
\end{tabular}

Here, ST refers to source text, TT1 is Target Text 1 and TT2 is Target Text 2.

It is easy to attach the cadence of original text when reading it, fusing the features of Chinese poems and folk songs. ST has achieved the lexical and syntactic equivalence and has a harmonious rhyme. However, we can hardly feel the features of Chinese poems and folk songs in the two TTs, so the author, according to the regional culture of Xi'an and features of folk songs, suggests translating ST in the following way.

\footnotetext{
Stool is to squat

Roof is to slope

Rag is to wrap
}

Miss never marries to other districts

Noodles are stretched as straps

Turning pasta as pot cover

Pouring oil into the crushed paprika

Roaring over the Shanxi opera

\section{CONCLUSION}

Chinese traditional culture is of great significance and plays an important role in college English teaching. However, there is an absence of Chinese culture in the current study of college English teaching and are fewer comprehensive researches in the aspects of course system, teaching idea, teacher team construction, textbook compilation and evaluation system. The 
reform in college English teaching requires to improve university students' attention to English learning of Chinese traditional culture, enhance teachers' cultural literacy, correct teachers and students' correct misunderstandings of crosscultural communication and cultural education, clearly define Chinese traditional culture in college English teaching and conduct new teaching practice, experiment and research on the mode and method of college English teaching. The reform of question styles of translation in CET 4 and CET 6 shows the vision expansion of college English teaching in cultural transmission. The inclusion of Chinese traditional culture in college English translation courses is an effective attempt and innovative practice.

\section{REFERENCES}

[1] Wang Yuxi. Thinking of several problems in college English translation teaching[J]. Chinese Translators Journal,2010,( 06) : 33.

[2] Wang Wei. New version of CET 4 translation in intercultural translation teaching model construction [J]. Education and Teaching Forum,2015(1):137-138.

[3] Deng Yanchang,Liu Runqing. Language and Culture-Cultural Contrast between English and Chinese Language[M]. Foreign Language Teaching and Research Press,2006. 177

[4] Wei Zhaoxi. Culture-theme exploration in practice of College English teaching $[\mathrm{M}]$. Beijing: China agricultural science and technology press,2010:194

[5] Nida, Eugene A. 1993. Language, Culture and Translating. Shanghai: Shanghai Foreign Language Education Press.

[6] Waard, J. \& Nida, E.A. 1986.From One Language to Another: Functional Equivalence in Bible Translating[M]. Nashville, Tennessee: Thomas Nelson, Inc.

[7] Sims, Martha; Martine Stephens (2005). Living Folklore. Logan, Utah: Utah State University Press. 